\title{
Taxonomic Review on the Genus Sciota (Lepidoptera, Pyralidae, Phycitinae) in Northeast China
}

\author{
Mu-jie Qi ${ }^{1}$, Bo-Sun Park ${ }^{1}$, Hui-lin Han ${ }^{2}$, Yang-Seop Bae ${ }^{1, *}$ \\ ${ }^{1}$ Biological Resource Environment Research Institute, \\ Division of Life Sciences, Incheon National University, Incheon 406-772, Korea \\ ${ }^{2} \mathrm{~S} c h o o l$ of Forestry, Northeast Forestry University, Harbin 150040, China
}

\begin{abstract}
Three species of the genus Sciota Hulst, 1888 are recognized from Northeast China: Sciota cynicella (Christoph, 1881), Sciota fumella (Eversmann, 1844), and Sciota adelphella (Fischer von Röslerstamm, 1836), of which Sciota cynicella (Christoph, 1881) is reported for the first time from China. This species can be distinguished from congeners by the gray color of basal area, the straight antemedial line and the distinct postmedial line on the forewing; by the stout aedeagus in male genitalia. In this study, a key to Northeastern Chinese species of genus Sciota is presented, and the illustrations of adults and genitalia are also provided.
\end{abstract}

Keywords: Lepidoptera, Pyralidae, Phycitinae, Sciota, new record, NE China

\section{NTRODUCTI ON}

The genus Sciota was established by Hulst (1888), with $S$. croceella Hulst as the type species from Texas, United States of America. This genus is similar to the related genus Nephopterix Hübner, 1825, but can be distinguished by the following characteristics: in the forewing, the $\mathrm{R}_{2}$ and $\mathrm{R}_{3+4}$ are approaching at base but not connate; in the male genitalia, the juxta is rounded or elongate without lateral lobes; in female genitalia, the corpus bursae is scobinate or with minute sclerites on inner surface. Currently, the genus Sciota comprises 40 species all over the world (Leraut, 2002; Neunzig, 2003; Slamka, 2010), of which four species were reported from the Far East of Russia, two species from South Korea, and five species from Japan (Yamanaka, 2001; Jinbo, 20042008; Bae et al., 2008; Kirpichnikova, 2009), and four species have been known in China (Xu, 1997; Li, 2012), the species are as follows: S. adelphella (Fischer von Röslerstamm, 1836), S. fumella (Eversmann, 1844), S. hostilis Stephens, 1834, and S. rhenella (Zincken, 1818). However, only S. adelphella (Fischer von Röslerstamm, 1836) has been reported from NE China. In the present study, we recognize three species of the genus Sciota: S. cynicella (Christoph, 1881), S. fumella (Evers- mann, 1844) and S. adelphella (Fischer von Röslerstamm, 1836), of which S. cynicella (Christoph, 1881) is newly recorded from China.

\section{MATERI ALS AND METHODS}

Materials used in this study were collected by light traps in NE China: Heilongjiang, Jilin, and Liaoning Provinces, and NE region of Inner Mongolia. Abbreviations used herein are as follows: TS, type species; TL, type locality.

\section{SYSTEMATI C ACCOUNTS}

Order Lepidoptera Linnaeus, 1758

Family Phycitinae Ragonot, 1885

\section{Genus Sciota Hulst, 1888}

Sciota Hulst, 1888: 115. TS: Sciota croceella Hulst, 1888. Apodentinodia Roesler, 1969: 252. TS: Dentinosa obscurella Caradja, 1937.

Clasperopsis Roesler, 1969: 248. TS: Selagia nigerrimella
(C) This is an Open Access article distributed under the terms of the Creative Commons Attribution Non-Commercial License (http://creativecommons.org/ licenses/by-nc/3.0/) which permits unrestricted non-commercial use, distribution, and reproduction in any medium, provided the original work is properly cited.

pISSN 2234-6953 eISSN 2234-8190
*To whom correspondence should be addressed

Tel: 82-32-835-8246, Fax: 82-32-835-0763

E-mail: baeys@incheon.ac.kr 


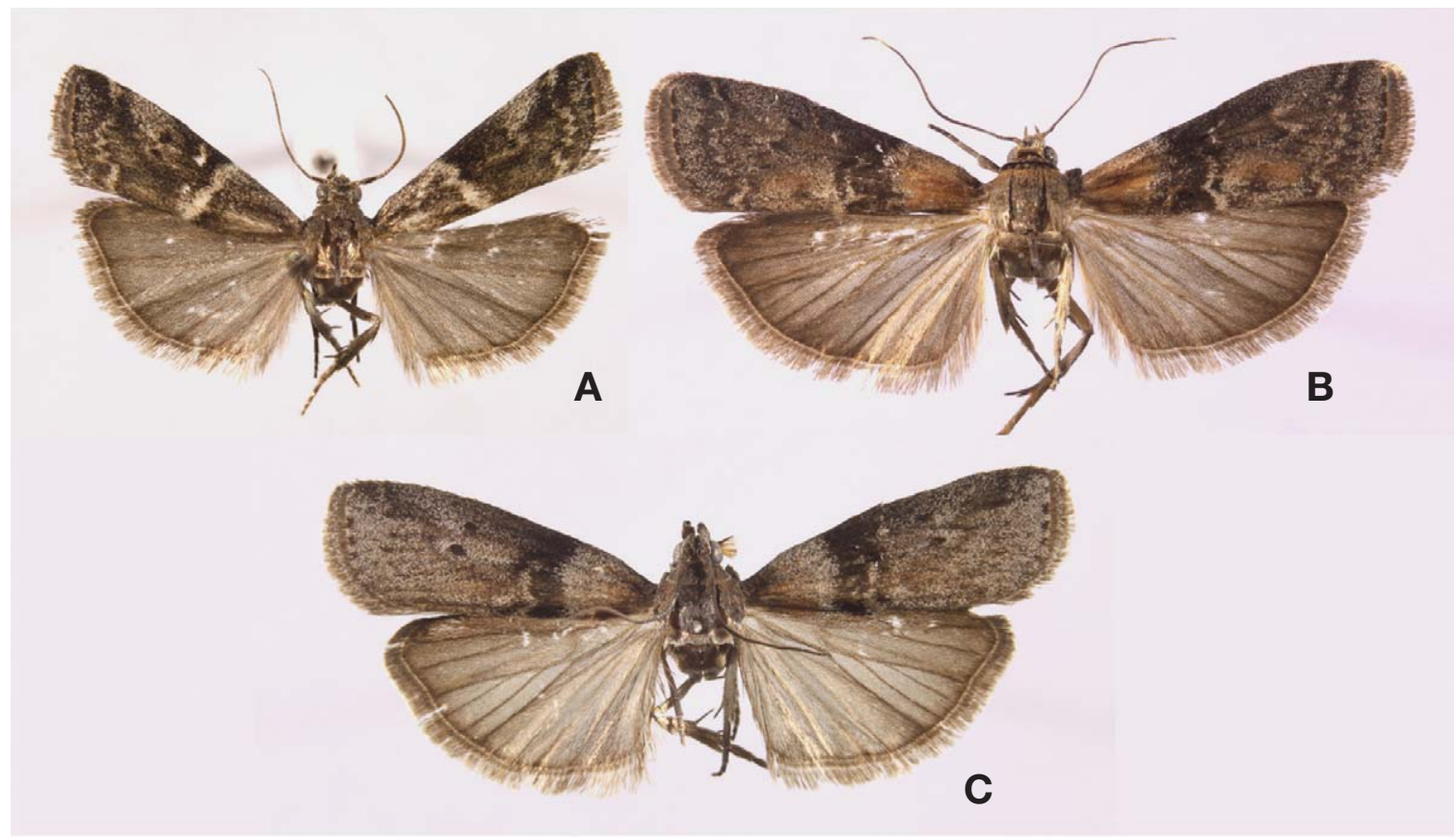

Fig. 1. Adults of genus Sciota. A, S. cynicella (Christoph, 1881); B, S. adelphella (Fischer von Röslerstamm, 1836); C, S. fumella (Eversmann, 1844).

Caradja, 1916.

Paranephopterix Roesler, 1969: 259. TS: Salebria barteli Caradja, 1910.

Adult. Wingspan 17-29 mm. Labial palpus upturned; maxillary palpus with long and slender scales in male, simple in female; antenna filiform, about 3/5-4/5 length of forewing, male with sinus at base of flagellum. Forewing with 11 veins; $\mathrm{R}_{2}$ and $\mathrm{R}_{3+4}$ approaching at base but not connate; $\mathrm{R}_{3+4}$ stalked with $R_{5}$ for $2 / 3$ length; $M_{2}$ and $M_{3}$ stalked at base. Hindwing with 10 veins; $S c+R_{1}$ and $R s$ approximate for $1 / 2$ length beyond discall cell; $\mathrm{M}_{2}$ and $\mathrm{M}_{3}$ stalked about $3 / 5$ length; discal cell about 1/3 length of hindwing.

Male genitalia. Uncus subtriangular; apical gnathos pointed or hooked; juxta rounded or elongate, without lateral lobes; aedeagus cylindrical, with $1-3$ cornuti.

Female genitalia. Ductus bursae slightly sclerotized, shorter than corpus bursae; corpus bursae oblong, scobinate on inner surface or with minute sclerites.

\section{Key to the genus Sciota Hulst from NE China}

1. Basal area of forewing covered with reddish gray or brownish yellow color; antemedial line dentate..$\ldots \ldots \ldots \ldots \ldots 2$

- Basal area of forewing gray; antemedial line straight; postmedial line distinct and dentate $. . . \ldots \ldots \ldots \ldots . . .$. S. cynicella

2. Antemedial line thin; postmedial line unclear; male genitalia with harpe rod-shaped, about $1 / 2$ length of valva .......
- Antemedial line dentate; postmedial line distinct; harpe rather small, thumb-shaped; transtilla knot-shaped on the top S. adelphella

Sciota cynicella (Christoph, 1881) (Figs. 1A, 2A, 3A) Myelois cynicella Christoph, 1881: 54. TL: Russia, Amur. Nephopteryx cynicella: Ragonot, 1893: 272; Rebel, 1901: 35. Sciota cynicella: Yamanaka, 2004: 188.

Material examined. China: $3 \diamond^{\nearrow}$, Mt. Bailang, Jianchang, Prov. Liaoning, 40 48'28' N, $119^{\circ} 54^{\prime} 16^{\prime \prime}$ E, 3 Jul 2012, legs. Qi MJ, Liu J, slide No. UIK-2755, 2756, 2748; 1 우, Mt. Bailang, Jianchang, Prov. Liaoning, 13 Jul 2011, leg. Qi MJ, slide No. UIK-2762.

Diagnosis. This species is similar with the congeners, but it can be distinguished by the following characteristics: basal area of forewing is covered with gray scales; antemedial line is straight; postmedial line is white and dentate. Male genitalia can be distinguished by the short aedeagus which is about 2/3 length of valva. Female genitalia can be distinguished by ductus bursae which is narrow at middle, and without sclerotized part; corpus bursae without patches on the inner surface.

Adult (Fig. 1A). Wingspan 17-21 mm. Vertex grayish white, frons fuscous mixed with gray, labial palpus with 2 nd and 3rd segment fuscous, inner side grayish white, 1st segment 

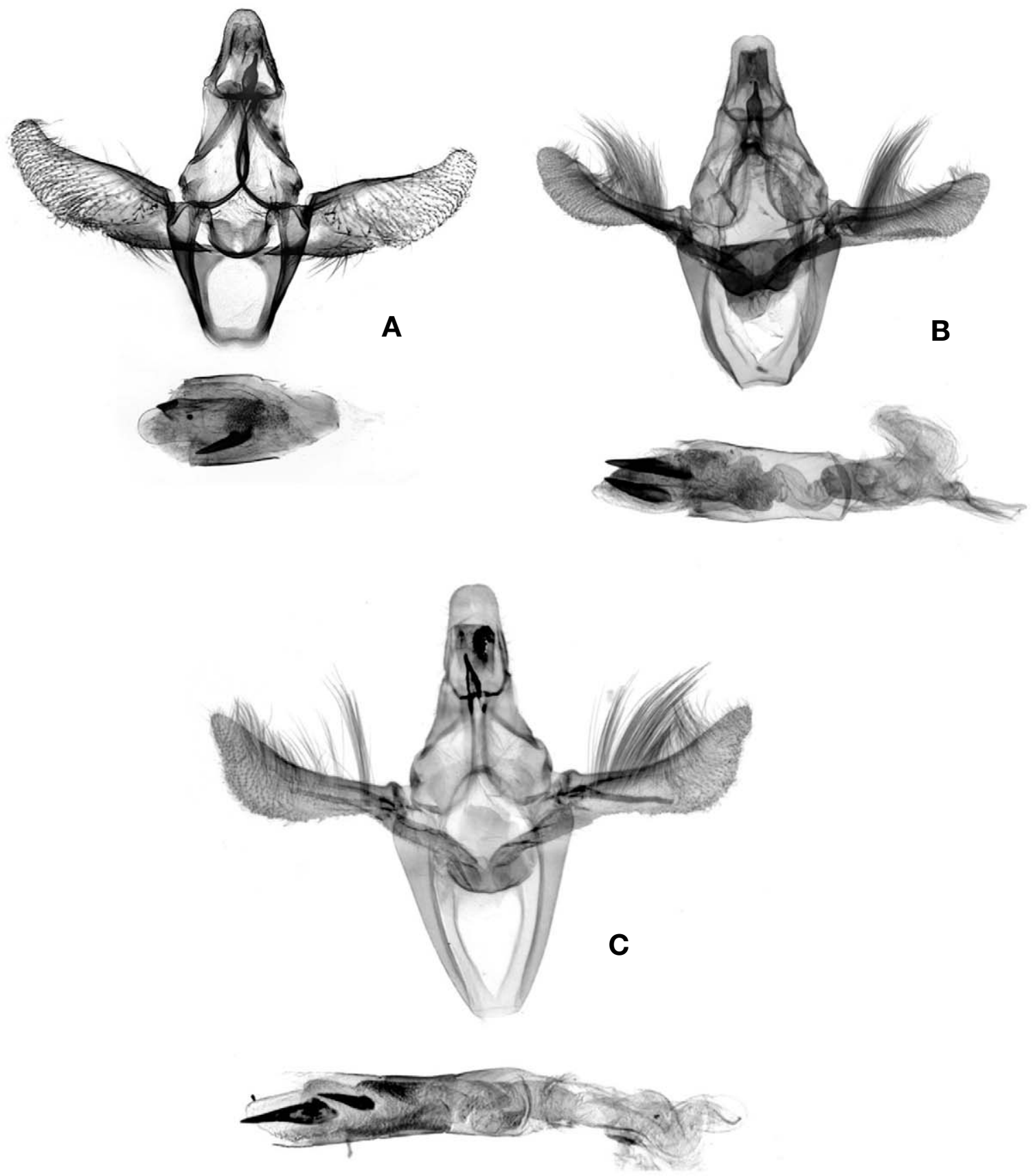

Fig. 2. Male genitalia of genus Sciota. A, S. cynicella (Christoph, 1881); B, S. adelphella (Fischer von Röslerstamm, 1836); C, S. fumella (Eversmann, 1844).

grayish white, 2nd segment about 3 times as long as 3rd segment, 1st and 3rd segment same in length, maxillary palpus about $2 / 3$ length of 2 nd segment of labial palpus, with tip grayish white, proboscis covered with fuscous scales at base, antenna fuscous; patagium and tegula fuscous; forelegs and middle legs with femur and tarsus fuscous mixed slightly with gray scales, tibia fuscous, each segments with gray tip; hindlegs with femur almost gray, tarsus grayish white, mixed with fuscous, tibia fuscous, each segment with gray tip. Forewing with ground color fuscous; antemedial line white, from $1 / 3$ of basal costa, oblique outwardly, dentate; postmedial line white, thiner than antemedial line, oblique inwardly from costa, sinuous; median area with triangular white patch along costa; two black distal discoidal spots separated, terminal 


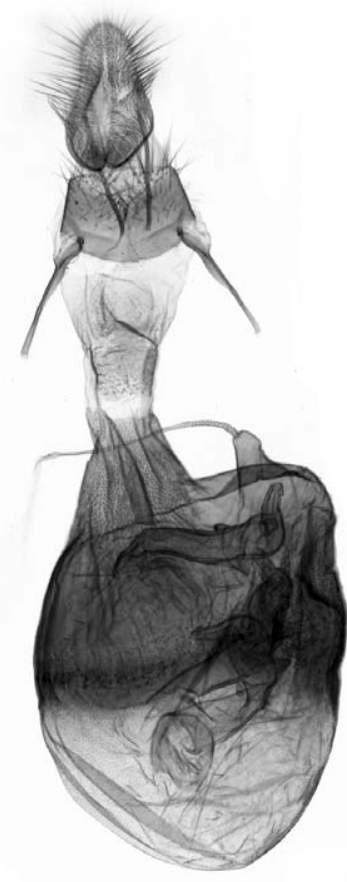

A

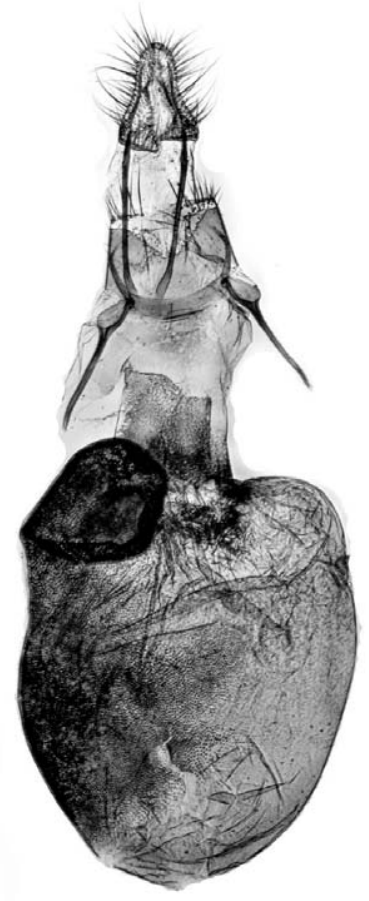

B

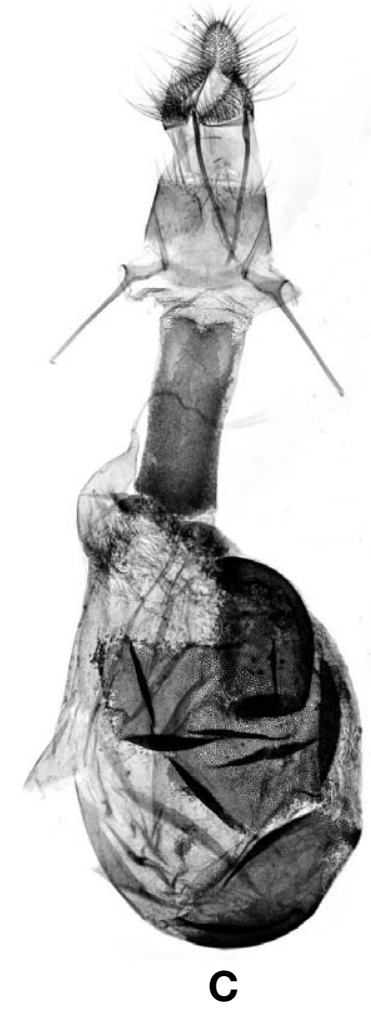

Fig. 3. Female genitalia of genus Sciota. A, S. cynicella (Christoph, 1881); B, S. adelphella (Fischer von Röslerstamm, 1836); C, S. fumella (Eversmann, 1844).

line gray, interneural spots black, fringe gray. Hindwing with ground color gray, terminal line pale gray, fringe brownish gray.

Male genitalia (Fig. 2A). Uncus subtriangular, rounded at top; gnathos coniform, with middle enlarged, pointed at tip, about $1 / 2$ length of uncus; valva curved upwardly, rounded at apex, costa well sclerotized, basal part broad, pointed at tip, shorter than length of valve, sacculus stick-shaped, about 2/5 length of valva, Juxta semicircular at base, lateral lobes oblong, with setae at tips; vinculum U-shaped, about 2/3 length of valva, saccus concave slightly; aedeagus rather stout, about $2 / 3$ length of valva, with two cornuti, bigger one thorn-shaped, smaller one comma-shaped.

Female genitalia (Fig. 3A). Apophyses posteriores about same length as apophyses anteriores, and with slightly enlarged base; antrum rectangular, with lateral sides slightly folded inwardly; anterior half of ductus bursae scobinate, corpus bursae oval, posterior part granulated, and with longitudinal wrinkles, signum absent; ductus seminalis from posterior part of appendix bursae.

Distribution. China (Liaoning), Japan, Russia (Primorye). Remarks. In the present study, this species is reported for the first time from China.
Sciota adelphella (Fischer von Röslerstamm, 1836)

(Figs. 1B, 2B, 3B)

Phycis adelphella Fischer von Röslerstamm, 1836: 50. TL: Japan.

Nephopterix adelphella: Inoue, 1954: 135; Park, 1983: 151; Sinev, 1986: 281.

Sciota adelphella: Emmet, 1988: 227.

Material examined. China: $1 \sigma^{\top}$, Mt. Bailangshan, Jianchang, Prov. Liaoning, 11 Jul 2011, leg. Qi MJ, slide No. UIK-2961; 1 ð , Mt. Bailangshan, Jianchang, Prov. Liaoning, $40^{\circ} 48^{\prime} 14^{\prime \prime} \mathrm{N}, 119^{\circ} 54^{\prime} 41^{\prime \prime} \mathrm{E}$, 4 Jul 2012, legs. Qi MJ, Liu J,

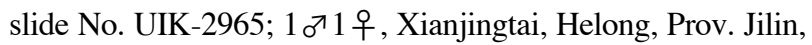
$42^{\circ} 18^{\prime} 49^{\prime \prime} \mathrm{N}, 129^{\circ} 04^{\prime} 13^{\prime \prime} \mathrm{E}, 10 \mathrm{Jul} 2012$, legs. Qi MJ, Liu J, slide No. UIK-2916, 2964; 1 우, Mt. Changbai, Erdao Electric Plant, Prov. Jilin, 42 $24^{\prime} 11^{\prime \prime} \mathrm{N}, 128^{\circ} 06^{\prime} 04^{\prime \prime} \mathrm{E}, 7$ Jul 2012, legs. Qi MJ, Liu J, slide No. UIK-2946; 2 우, Mt. Changbai, West Gate, Prov. Jilin, China, $42^{\circ} 03^{\prime} 09^{\prime \prime} \mathrm{N}, 127^{\circ} 39^{\prime} 44^{\prime \prime} \mathrm{E}, 8$ Jul 2012, legs. Qi MJ, Liu J, slide No. UIK-2958, 2960; 3 우, Changxin Forestry Center, Helong, Prov. Jilin, 42 ${ }^{\circ} 19^{\prime}$ $51^{\prime \prime} \mathrm{N}, 128^{\circ} 57^{\prime} 14^{\prime \prime} \mathrm{E}, 11 \mathrm{Jul} 2012$, legs. Qi MJ, Liu J, slide No. UIK-2655, 2943, 2947.

Diagnosis. This species is similar with the congeners, but it 
can be distinguished by the following characteristics: basal area of forewing is covered with reddish gray scales; antemedial line is white, sinuous and clear; postmedial line is grayish white and dentate. Male genitalia can be distinguished by the rather small and thumb-shaped harpe. Female genitalia can be distinguished by ductus bursae which is about $1 / 2$ length of corpus bursae, and only $1 / 3$ of anterior part is sclerotized; lateral and posterior part of corpus bursae with granule and patches on inner surface.

Adult (Fig. 1B). Wingspan 21-29 mm. Labial palpus fuscous; basal area and posterior part of median area of forewing pale yellowish gray or reddish gray; antemedial line white, sinuous and clear; postmedial line grayish white and dentate.

Male genitalia (Fig. 2B). Gnathos rectangular at base, small thorn-shaped at top, about 1/2 length of uncus; transtilla connected at top, the connection knot-shaped or quadrate; valva with apical part rounded; harpe rather small, thumbshaped; vinculum U-shaped, same length with valva.

Female genitalia (Fig. 3B). Ductus bursae straight, about $1 / 2$ length of corpus bursae, only $1 / 3$ of anterior part sclerotized; lateral and posterior part of corpus bursae with granule and patches on inner surface.

Distribution. China (Jilin, Liaoning, Inner Mongolia, Hebei, Henan, Jiangxi, Anhui, Hubei, Sichuan, Fujian, Shaanxi, Qinghai), Korea, Japan, Russia, Europe (Germany, Hungary, France, Netherlands).

Sciota fumella (Eversmann, 1844) (Figs. 1C, 2C, 3C)

Phycis fumella Eversmann, 1844: 558. TL: Russia.

Nephopterys [sic] fumella: Herrich-Schäffer, 1848: 72.

Nephopteryx [sic] tristis Alphéraky, 1880: 47. TL: Russia,

Amur, Tangarog.

Salebria fumella: Ragonot, 1893: 355.

Selagia nigerrimella Caradja, 1916: 11. TL: Sajan, Arasagun gol.

Nephopterix (Clasperopsis) nigerrimella: Roesler, 1969: 249.

Nephoterix fumella: Sinev, 1986: 281; Paek and Bae, 2001: 303.

Sciota fumella: Palm, 1986: 41, Pl. 1, fig. 20.

Material examined. China: $1 \sigma^{\nearrow 1} 1$ 우, Mt. Bailangshan, Prov. Liaoning, $40^{\circ} 48^{\prime} 28^{\prime \prime} \mathrm{N}, 119^{\circ} 54^{\prime} 16^{\prime \prime} \mathrm{E}, 11$ Jul 2011, legs. Qi MJ, slide No. UIK-2959, 2962; 5 『 , Xianjingtai, Prov. Jilin, $42^{\circ} 18^{\prime} 49^{\prime \prime} \mathrm{N}, 129^{\circ} 04^{\prime} 13^{\prime \prime} \mathrm{E}, 10 \mathrm{Jul} 2012$, legs. Qi MJ, Liu J,

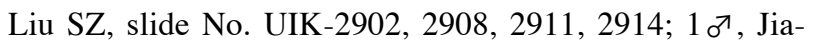
gedaqi, Daxinganling, Prov. Heilongjiang, $50^{\circ} 11^{\prime} 51^{\prime \prime} \mathrm{N}, 124^{\circ}$ $12^{\prime} 18^{\prime \prime}$ E, 18 Jul 2012, legs. Qi MJ, Liu J, slide No. UIK2845.

Diagnosis. This species is similar with the congeners, but it can be distinguished by the following characteristics: base of forewing is pale yellowish gray, and the antemedial line is thin; postmedial line is unclear. Male genitalia can be distinguished by trapezoid uncus; gnathos is coniform and about $1 / 3$ length of uncus; harpe is rod-shaped, and about $1 / 2$ length of valva. Female genitalia can be distinguished by the ductus bursae which is straight and almost sclerotized, and about same length as corpus bursae; anterior, middle and posterior part of corpus bursae with granule and patches on inner surface.

Adult (Fig. 1C). Wingspan 22-26 mm. Labial palpus with inner side brownish yellow; base of forewing pale yellowish gray, antemedial line thin and only posterior part clear; postmedial line unclear.

Male genitalia (Fig. 2C). Uncus trapezoid; gnathos coniform, about 1/3 length of uncus; valva with apical part sharped; harpe rod-shaped, about 1/2 length of valva; vinculum Ushaped, with saccus flat.

Female genitalia (Fig. 3C). Ductus bursae straight and almost sclerotized, about same length as corpus bursae; anterior, middle and posterior part of corpus bursae with granule and patches on inner surface.

Distribution. China (Heilongjiang, Jilin, Liaoning, Henan, Hebei, Yunnan), Japan, Russia, Europe.

Remarks. In this study, it is reported for the first time from Northeast China.

\section{ACKNOWLEDGMENTS}

We thank Dr. Valentina Kirpichnikova, Mountain-Taiga Station, Far Eastern Branch of Russian Academy of Sciences, for her help and sending references. We are grateful to Dr. Bicha, Oak Ridge National Laboratory, USA, who reads the original manuscript carefully before submitting. We also express thanks to students of the Laboratory of Insects Taxonomy, Northeast Forestry University, for their help in field trips. Financial support was provided by the National Institute of Biological Resources (NIBR) of Ministry of Environment, KOREA (1834-302). "Graduate Program for the Undiscovered Taxa of Korea”.

\section{REFERENCES}

Alphéraky S, 1880. Nephopteryx tristis Alphéraky. Trudy Russkago Entomologiceskago Obscestva, 11:47.

Bae YS, Byun BK, Paek MK, 2008. Pyralid Moths of Korea (Lepidoptera, Pyraloidea). Korea National Arboretum, Seoul, pp. 1-426.

Caradja A, 1916. Beitrag zur Kenntnis der geographischen Verbreitung der Pyraliden und Tortriciden des europäischen Faunengebietes, nebst Beschreibung neuer Formen. Deutsche Entomologische Zeitschrift Iris, 30:1-88. 
Christoph HT, 1881. Neue Lepidopteren des Amurgebietes. Bulletin de la Société Impériale des Naturalistes de Moscou, 56:1-80.

Emmet AM, 1988. A Field Guide to Smaller British Lepidoptera. British Entomological \& Natural History Society, London, pp. 1-288.

Eversmann E, 1844. Fauna Lepidopterologica Volgo-Uralensis. Typis Universitatis, Casani, pp. 1-633.

Fischer von Röslerstamm JE, 1834-1843. Abbildungen zur Berichtigung und Ergänzung der Schmetterlingskunde, besonders der Microlepidopterologie als Supplement zu Treitschke's und Hübner's europaeischen Schmetterlingen, mit erläuterndem Text. Hinrichs, Leipzig, pp. 1-304.

Herrich-Schäffer GAW, 1847-1855. Systematische Bearbeitung der Schmetterlinge von Europa, zugleich als Text, Revision und Supplement zu Jakob Hübner's Sammlung europäischer Schmetterlinge. 5: Die Schaben und Federmotten. G. J. Manz, Regensburg, pp. 1-394.

Hulst GD, 1888. New genera and species of Epipaschiae and Phycitidae. Entomologica Americana, 4:113-118.

Inoue H, 1954. Pyralidae. Checklist of the Lepidoptera of Japan. Vol. 2. Rikusuisha, Tokyo, pp. 120-196.

Jinbo U, 2004-2008. List MJ: A checklist of Japanese moths [Internet]. Tokyo, Accessed 1 May 2013, <http://listmj.moth prog.com>.

Kirpichnikova VA, 2009. Pyralids (Lepidoptera, Pyralidae, Crambidae) of the fauna of Russian Far East. Dalnauka, Vladivostok, pp. 1-518.

Leraut PJA, 2002. Contribution à l'étude des Phycitinae (Lepidoptera, Pyralidae). Nouvelle Revue d'Entomologie, 19:141177.

Li HH, 2012. Microlepidoptera of Qinling Mountains (Insecta: Lepidoptera). Science Press, Beijing, pp. 1-1271.

Neunzig HH, 2003. Pyraloidea, Pyralidae. Phycitinae. In: The moths of America North of Mexico including Greenland, fasc. 15.5 (Ed., Dominick RB). The Wedge Entomological Research Foundation, Washington, DC, pp. 1-338.
Paek MK, Bae YS, 2001. A revision of the genus Nephopterix Hübner (Lepidoptera, Pyralidae, Phycitinae, Phycitini) from Korea. Insecta Koreana, 18:293-306.

Palm E, 1986. Nordeuropas Pyralider - med saerligt henblik paa den danske fauna (Lepidoptera: Pyralidae). In: Danmarks Dyreliv. Fauna Bøger 33 (Ed., Lyneborg L). National-Trykkerit, Copenhagen, pp. 1-287.

Park KT, 1983. Microlepidoptera of Korea. Insecta Koreana, 3:1-195.

Ragonot EL, 1893. Monographie des Phycitinae et des Galleriinae. In: Mémoires sur les Lépidoptères. Vol. 7 (Ed., Romanoff NM). Imprimerie de M.M. Stassuléwitch, St. Petersburg, pp. 1-658.

Rebel H, 1901. Pyralidae. In: Catalog der Lepidopteren des Palaearctischen Faunengebietes. Vol. 2 (Eds., Staudinger O, Rebel H). R. Friedländer \& Sohn, Berlin, pp. 1-70.

Roesler RU, 1969. Phycitinen-Studien VII (Lepidoptera, Pyralidae). Entomologische Zeitschrift, 79:245-260.

Sinev SY, 1986. Keys to the insects of the European part of U.S.S.R. Lepidoptera. Family Phycitinae. Opredeliteli Faune SSSR, pp. 251-340 (in Russian).

Slamka F, 2010. Pyraloidea (Lepidoptera) of Central Europe: identification, distribution, habitat \& biology. Bratislava, pp. $1-176$.

Xu ZG, 1997. Iconographia of Microlepidoptera in Qinghai Province of China. China Agricultural Science and Technology Press, Beijing, pp. 1-186.

Yamanaka H, 2001. Notes on three unrecorded and two little known species of the Phycitinae (Pyralidae) from Japan. Japan Heterocerists' Journal, 215:275-282.

Yamanaka H, 2004. Two new species, three unrecorded species, and three new synonyms of the Phycitinae from Japan (Pyralidae). Tinea, 18:184-191. 